\title{
Perceptions of Primary School Teacher Candidates towards the Turkish Education System, School, Teacher, and Student: A Metaphor Analysis
}

\author{
Emel Tüzel İşeri ${ }^{1} \&$ Uğur Akin ${ }^{1}$ \\ ${ }^{1}$ Tokat Gaziosmanpaşa University, Turkey \\ Correspondence: Emel Tüzel İşeri, Tokat Gaziosmanpaşa University, Turkey. E-mail: emeltuzel@ hotmail.com
}

Received: July 12, 2019

Accepted: August 6, 2019

Online Published: August 19, 2019

doi:10.5430/ijhe.v8n4p239

URL: https://doi.org/10.5430/ijhe.v8n4p239

\begin{abstract}
This study aimed to determine the perceptions of primary school teacher candidates about the Turkish education system, school, teacher, and student concepts by means of metaphors. The study group consisted of 82 primary school teacher candidates enrolled in the senior class of a university in the Black Sea Region in Turkey in 2018. The study data were collected using a questionnaire which involved gap filling questions aiming to determine the metaphors for the Turkish education system, school, teacher, and student. Findings indicated that the majority of the primary school teacher candidates had a negative perception of the Turkish education system. More than half of the negative metaphors that the participants used were about the unceasing change of the system. Primary school teacher candidates' perceptions of the school concept were mostly positive. The participants saw school as a home that educates and shapes people. Nevertheless, a considerable number of the participants considered school like an oppressive and uniformizing prison, where they would not like to be. Majority of the primary school teacher candidates had positive perceptions of the teacher concept. Nonetheless, there were neutral and negative perceptions as well. The participants mostly emphasized the educating and shaping characteristics of the teacher concept in their descriptions. Although primary school teacher candidates' perceptions of student were generally positive, a student description, in which student was seen passive in the learning process and highlighted as an entity that can be shaped, stood out.
\end{abstract}

Keywords: metaphors, Turkish education system, school, teacher, student

\section{Introduction}

The concepts shaping the way we think are not related to the human mind only, they also guide the daily flow of life thoroughly. Our concepts govern what we perceive, how we move around the world, and how we establish relationships with other people. For these reasons, our conceptual system plays a significant role in determining our daily life realities. Our conceptual system is largely shaped by metaphoric thinking. Therefore, our experiences and our daily life activities have a lot to do with metaphors to a considerable extent. Metaphors are the products of our efforts to understand one thing by means of another (Lakoff \& Johnson, 1980). The word "metaphor" derived from the Greek word "metapherein". Meta means "to change" and herein means "to bear". In this sense, metaphors are used as "changebearing" agents (Levine, 2005). We employ metaphors when trying to understand unusual, abstract, too unknown, or speculative things. The more abstract and speculative the concept the greater the variety of metaphors employed to understand the concept (Yob, 2003). Metaphors function as powerful mental mapping and modeling mechanisms allowing individuals to understand and construct realities of their own world (Arslan \& Bayrakc1, 2006). Not only do metaphors serve to embellish speech, but they are also a functional means of thinking and reasoning (Martinez, Sauleda, \& Huber, 2001).

Metaphors are effective tools that help combine past and present, and theory and practice. Therefore, metaphors can help us to determine ways to develop teaching and learning activities (Levine, 2005). Research on metaphor carried out in the field of education, many variables related to teacher, school, and education have been explained by comparing them to very different things. Metaphors are about how we see the world and give us the chance to explore the essence of phenomena (Boostrom, 1998). By using metaphors and visual images, educators have the opportunity to have deeper insights into their roles and responsibilities, the nature of education, and teacher-student relationships (Çelikten, 2006). Concurrently, metaphors play a critical role in recognizing similar complex concepts about teaching, learning, and education, and provide effective ways of making sense of people's personal experience of these concepts (Saban, 2003). Metaphor studies have often resorted to understanding the phenomena in education 
for the past few decades. An important branch of metaphor studies in the field of education has considered teacher training and perceptions of teacher candidates about the variables of education. The significant question addressed here is: Can metaphors be tools to help us understand and enhance the nature of teacher education?

One of the reasons why teacher candidates cannot fully learn some concepts such as child, learning, education, program, and teaching, which are intended to be given in educational faculties, is that our perceptions of these concepts are quite different than those of students (Mahlios \& Maxson, 1998). Teacher candidates' perceptions about teaching are one of the important variables that shape their future professional roles, identities, and practices (Saban, 2003). Teaching is a profession that requires successful management of challenging relationships with students, parents, teachers, and other interested parties. According to some researchers (e.g. Goldstein, 2005), students', and others' expectations from teachers are tough enough to be expected from a hero. Metaphors can be employed as effective tools to help teachers make sense of these challenging roles more effectively. In support of this argument, Carlson's study (2001) found that metaphors helped prospective teachers understand abstract and complex concepts of the teaching process and teaching profession more easily.

It can be argued that there is relatively large literature addressing teacher candidates' perceptions of the educational process in Turkey by using metaphors. Of the existing studies, Saban's study (2003) reported that teacher candidates perceived the student as "raw material to be processed", "a patient to be healed", "a child to be raised in a loving family", "a horse to be prepared for races", " a passenger to be taken to certain stops by bus", and "a team player who should actively participate and collaborate". Within the scope of this perception towards student, school was described as a "factory", "hospital", "family", "hippodrome", "bus", and "team" while teacher was described as a "manufacturer", "doctor", "parent", "jockey", "driver", and "coach". In this study, the perceptions of teacher candidates about these concepts of education were found to be greatly influenced by their own experiences as a student. Bramald, Hardman, and Leat (1995) stated that teacher candidates' perceptions of learning and teaching concepts were greatly influenced by their own past experiences as a student, which supports the aforementioned finding. Based on these two studies and findings, the experiences of teacher candidates as students while they were at the faculty of education and before they arrived can be argued to shape their perceptions of education to a great extent.

In addition to experiences as a student, vocational education received in educational faculties can undoubtedly be considered as an important variable in the perceptions of teacher candidates about education. In support of this argument, the study of Ocak and Gündüz (2006) revealed that teacher candidates' perceptions of the teacher concept might be influenced by vocational courses on the teaching profession. According to the results of their study, while teacher candidates described teacher as "parent" under the theme of "sacrifice" before taking the "Introduction to Teaching Profession" course, after taking the course, they opted for "source of knowledge" theme by highlighting "gardener", and "sun" metaphors. The findings of this study are important in terms of showing that teacher education can shape students' conceptual construct related to education. Perhaps another "implicit finding", as important as this, laid out by the study is the fact that metaphors are effective tools for identifying changing conceptual constructs.

Studies investigating teacher candidates' perceptions of various concepts related to education through metaphors have endeavored to reveal perceptions about various variables related to the education process such as the Turkish education system, school, teacher, and student. While some of these studies have addressed one or more concepts related to education from the perspective of teacher candidates, a smaller number of them have centered on the perceptions of classroom teachers, who are the focal point of the present study.

\subsection{Metaphors about Turkish Education System}

Örücü (2014) found that teacher candidates' perceptions of the Turkish education system were generally negative. In their study, the leading metaphors used by the participants relating to the Turkish education system were determined to be "horse racing", "experiment board", "labyrinth", and "deadlock". Similarly, the results of the study carried out by Kasapoğlu (2016) showed that prospective teachers perceived the Turkish education system mainly as an "unstable", "disorganized", and "complex" structure. Some metaphors forming the basis of these perceptions were "jigsaw", "play dough", "test board", "tarhana soup (a traditional Turkish soup)", "Noah's pudding (a traditional Turkish food)", and "labyrinth". The findings of Koçak (2013) revealed that teacher candidates' perceptions of MoNE (Ministry of National Education) were mostly shaped by metaphors related to politics. These findings involved criticisms of the frequent changes and the complex structure. Keser Özmantar and Yalçın Arslan (2019) determined that English teacher candidates' perceptions of basic variables related to the Turkish education system were generally positive. Nonetheless, the review of the research into the perceptions of primary school teacher candidates about the Turkish education system revealed a gap in the literature regarding the present issue. 


\subsection{School Metaphors}

The findings of Örücü (2014) and Cerit (2006) suggested that teacher candidates had a relatively positive perception of school. Cerit's (2006) study, while the participants adopted metaphors such as "place of knowledge and enlightenment", "place of growth and maturation", "family", and "team" for school, they did not prefer metaphors such as "chaotic environment", "prison", "factory", "office", and "shopping center". The findings of Saban (2008) showed that teacher candidates perceived school more like a place for "work", "production", and "growing crops". According to the findings of Nalçacı and Bektaş (2012), teacher candidates defined school using metaphors such as "family", "life", "prison", "factory", and "society". Doğan (2014) proposed that teacher candidates perceived school as "a place of love and solidarity", "a part of life", "a disciplinary place", and "a place of production". The results of the study conducted by Aydoğdu (2008) through metaphors produced by students and teachers showed that the main task of schools was perceived as providing information, protecting, and raising the new generation. According to the results of the same study, schools were seen as over-disciplined places. Saban (2003) reported that primary school teacher candidates produced some school-related metaphors such as "family (a loving and protective environment)", "garden (where individual needs and interests are met)", "restaurant (where a qualified service is received)", "team (where active participation and collaboration is achieved)", "island (a place discovered and investigated with the help of a guide)", and "circus (a place of fun and pleasure accompanying learning)". Similarly, primary school teacher candidates in the United States (e.g. Mahlios \& Maxson, 1998) thought that the school should be similar to a family or a team. According to Baker (1991), the leading metaphors used for understanding the school concept were "firm", "family", "fair", and "forum". According to the "firm" metaphor, the objective of school is to maximize academic production. As a family, school should provide children with an emotionally healthy and safe social environment. As a "fair", school is a place where students find the opportunity to gain appreciation by displaying their talents. As a "forum", school is a place where students have the opportunity to express their opinions freely as a requirement of a democratic society.

\subsection{Teacher Metaphors}

Cerit (2008) reported that students, teachers, and school administrators adopted positive metaphors about the teacher concept, such as "source and dispenser of information", "mother/father", "friend", "guide and a person who illuminates their circles". On the other hand, students and educators were found to not adopt metaphors such as "authoritarian person", "caregiver", and "guardian", which may be evaluated negatively. The results of the study carried out by Koç (2014) examining teacher candidates' perceptions of teacher laid out that perceptions about the teacher concept were positive, but that some negative metaphors related to teaching profession were produced. These negative metaphors were found to be expressed because the participants saw the teaching as a tough, ambiguous, and rule-based profession. In the study conducted by Saban, Koçbeker, and Saban (2006), teacher candidates described teachers as an information provider (e.g. sun, candle, fruit tree), facilitator (e.g. compass, lighthouse, north star), formative/craftsman (e.g. sculptor, painter, master), grower (e.g. gardener, farmer), and model (e.g. parents, friends). According to the findings of Yılmaz, Göçen, and Yılmaz (2013), teacher candidates perceived teachers more like a "shaper", "guiding", and "source of information", and they expressed these metaphors as "parents", "family", "gardener", "guide", "light", and "shepherd". Similarly, in the study of Pektaş and Kıldan (2009), the metaphors such as "sun (guiding)" and "gardener (formative)" came to the fore. Kiral (2015) found that teacher candidates' perceptions of the teacher concept were generally positive. In this study, metaphors that depicted teachers with characteristics such as "guiding (compass)", "treating (doctor)", and "giving information (book)" emerged. On the other hand, the findings of Şahin and Sabancı (2018) indicated that teacher candidates defined teachers with positive concepts such as "shelter", "source of inspiration", and "expert". Moreover, Turan, Yildırım, and Tikman (2016) determined that teacher candidates described teachers with metaphors such as "candle", "mother", "sun", "gardener", "family", and "parents".

In addition to the research on the perceptions of teacher candidates from different branches in education faculties about the teacher concept in general, studies addressing the metaphoric perceptions of teacher candidates about teachers of their own branch are also common. In these studies, teacher candidates described physical education teachers as "close to students", "a person helping and guiding students", and "a versatile person" (Yüksel, Sütçü, \& Özdemir, 2019); mathematics teachers as "knowledgeable" and "authoritarian" (Şahin, 2013); geography teachers as "a person guiding" (Alım, Sahin, \& Meral, 2018); history teachers as "a person storing and transferring historical information" and "illuminating and guiding" (Çulha Özbaş, \& Aktekin, 2013); and art teachers as "a person directing-guiding" (Bedir Erişti, 2017; Kalyoncu, 2012). The study of Kahya (2018) showed that prospective literature teachers had more traditional teaching perceptions of current literature teachers (as a person who is the source of information or guiding others). Similarly, Turkish Language teachers were defined by their traditional 
teaching roles as "information provider", "shaper" (Karabay, 2016), "information source", "producer", "formative" (Aydın \& Pehlivan, 2010). Teacher candidates described science teachers through concepts such as "guiding-directing" (Afacan, 2011), "family" (Yadigaroğlu, Demircioğlu, Yadigaroğlu, \& Akar, 2018); social science teachers as "enlightening/information source", "protector/manager", and "guide/instructor" (Uslu, 2015); and pre-school teachers as a "model" and "a person meeting the needs" (Akgün, 2016; Giren, 2015).

As is known, classroom teachers in Turkey teach primary school students from the first to fourth grades in the course of four years. The age of these students ranges between six and nine. Since the target age group is young, the perception towards these teachers may be expected to be more different. In support of this inference, Budak and Kula (2017) found that primary school teacher candidates mostly compared the teaching profession to the concept of "motherhood". In addition, themes such as "companion" and "guide" (Işık, 2014), "the source and transmitter of information", "shaping and formatting students", and "treating students" (Saban, 2004) were observed to come to the fore. Saban (2003) reported in another study that the most preferred metaphors for primary school teachers were "parent", "gardener", "chef", "coach", "tourist guide", and "entertainer".

\subsection{Student Metaphors}

The study of Koçak (2013) indicated that teacher candidates described their perceptions of the teacher concept with proactive metaphors while describing their perceptions of the student concept with reactive metaphors. In support of this finding, Aydın and Pehlivan (2010) found that teacher candidates described student as "information receiver", "produced", and "shaped". Furthermore, the findings of Saban $(2009 ; 2010)$ showed that teacher candidates saw students as an "empty mind", "information receiver", "raw material", and "empty container". Another noteworthy point was that the perception of primary school teacher candidates with this respect was higher than those of field teachers. Mahlios and Maxson (1998) reported that primary school teacher candidates preferred to portray the ideal student using the adjective "respectful". This perception of the ideal student supports a reactive student perception in addition to its positive meaning.

\subsection{The Aim of the Study}

As can be seen, even though there is a relatively large literature on teacher candidates' perceptions about various variables of the educational process, studies investigating primary school teacher candidates' perceptions of educational variables are limited in number. This study is thought to make important contributions to the literature by investigating the metaphoric perceptions of primary school teacher candidates about the Turkish education system, school, teacher, and student all together.

The aim of this study is to reveal the perceptions of primary school teacher candidates about the Turkish education system, school, teacher, and student through metaphors. In the study, the following research questions were asked.

1. What are the metaphorical perceptions of primary school teacher candidates about the Turkish education system?

2. What are the metaphorical perceptions of primary school teacher candidates about school?

3. What are the metaphorical perceptions of primary school teacher candidates about teacher?

4. What are the metaphorical perceptions of primary school teacher candidates about student?

\section{Methodology}

\subsection{Research Design}

This study has a phenomenological design which used a qualitative research method. The phenomenological design allows an in-depth study of phenomena which are perceived, but not fully understood, and about which all known is superficial (Creswell, 2012). In the phenomenological design, individuals or groups who experience the phenomenon that the research focuses on as the data source and who can reflect this phenomenon are targeted (Yıldırım \& Şimşek, 2011). With the help of this pattern, the study aimed to describe perceptions of primary school teacher candidates, who are currently studying in the Turkish education system and who will contribute to education by working in the Turkish education system after their graduation, towards the Turkish education system, school, teacher and student.

\subsection{Study Group}

The study was carried out with 82 primary school teacher candidates (all volunteer students from classroom teaching program's $4^{\text {th }}$ class), who were recruited using criterion sampling method (Yıldırım \& Şimşek, 2011), agreed to participate in the study, and were enrolled in the senior grade of a state university in Black Sea Region in Turkey in 2018. The critter we used was having so many experience as a primary school teacher candidate and so being in 
senior grade (being in fourth class). Of the teacher candidates participating in the study, 62 were females and 20 were males. For ethical issues, volunteer participants informed about all research procedure and researchers clarified that all responses would be used anonymously, hiding their identity.

\subsection{Instruments and Procedures}

In the data collection process, a questionnaire form containing gap-filling questions was used for determining the metaphors that teacher candidates used about the Turkish education system, school, teacher, and student. The participants were asked about what they see the Turkish education system, school, teacher and student like and the reason for this analogy. The questions were as follows:

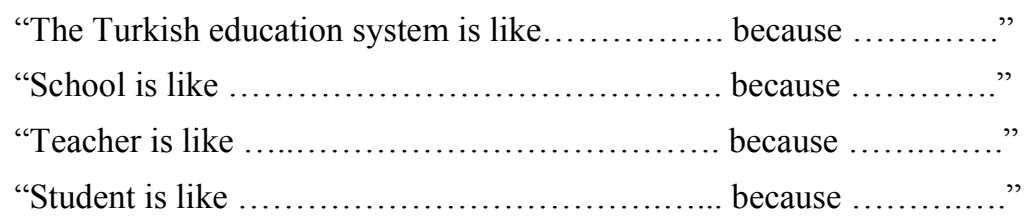

The data collection process was implemented in two sessions, the first of which consisted of 39 and the second 43 teacher candidates, because they were registered to different divisions of primary teaching education program as class A and class B. The questionnaire forms were handed out to the teacher candidates and they were given approximately 15 minutes in both sessions to fill out the forms. The participants were told that the data would be used for scientific purposes, and their identities would be kept confidential. Accordingly, they were asked to not write their names on the forms. The participants were informed that the forms would be coded as K1, K2, .. K82 and shared in this fashion.

\subsection{Data Analyses}

The data obtained from the teacher candidates were first evaluated in terms of whether they qualified as metaphors. Yıldırım and Şimşek (2011) state that metaphors cannot reveal their descriptive power by themselves; therefore, it must be asked with the "why" question. These "adjectives" provide the power of metaphors. Each individual can add different meanings to the same metaphor. These differences or the purpose of using a metaphor can only be found by answering the "why" question. The question forms which did not have a metaphor in the first gap (e.g. there is too much malfunction in the Turkish education system because the system is inefficient) and / or which did not involve a clear reason for the metaphor in the second gap (e.g. the school is like a prison because it looks very much like a prison) were excluded from the analysis.

The data evaluated as metaphors were subjected to content analysis. In content analysis, similar data are brought together under certain concepts and themes and they are organized and interpreted in a form that can be understood by the readers of the study (Creswell, 2012). The metaphors produced by the teacher candidates were coded, and the ones with similar and close meaning, as seen in the explanatory parts of the metaphors, were evaluated together and sub-themes were determined. Some metaphors (e.g. family, candle, house etc.) in the study data were found to be written with different explanations (e.g. the family metaphor was explained by one of the participants with a sense of belonging, while the other was given by the cosmopolitan / complex. For this reason, sub-themes were separated according to the explanatory part, not according to the metaphors created. When the sub-themes were evaluated altogether, it was observed that Turkish education system, school, teacher, and student concepts could be grouped under three different themes including positive, negative, and neutral/descriptive in all questions.

The number of repetitions (f) for each code, sub-theme, and theme was calculated, and the perceptions of teacher candidates about the Turkish education system, school, teacher, and student were interpreted accordingly.

\subsection{Validity and Reliability}

The internal validity of the study was achieved by means of content validity of the questionnaire form containing the study questions. The questionnaire form required teacher candidates to explain the concepts of Turkish education system, school, teacher, and student as metaphors. Before starting the data collection process, the questionnaire form was submitted to the opinion of three experts including one from the field of measurement and evaluation and the others from the field of educational management, and then the suitability of the form was confirmed. The study process was presented to provide generalizability. In order to achieve the internal reliability (consistency), codes, sub-themes, and themes were created and compared separately by each two researchers and finalized by consensus. In addition, the final codes, sub-themes, and themes were submitted to three experts including one from the primary school teaching field, one from the educational management field, and one from the measurement and evaluation field in education. 


\section{Results}

\subsection{Teacher Candidates' Metaphorical Perceptions about Turkish Education System}

The first question of the study was about teacher candidates' metaphoric perceptions of Turkish education system. Table 1 presents the themes, sub-themes, and codes of the data analyzed to find an answer to this question.

Table 1. Metaphors about Turkish education system $(\mathrm{N}=82$, Valid=80)

\begin{tabular}{|c|c|c|}
\hline Themes & Sub-themes & Codes \\
\hline \multirow{13}{*}{$\begin{array}{l}\text { Negative perception } \\
(\mathrm{f}=62)\end{array}$} & \multirow{7}{*}{ Constantly changing $(\mathrm{f}=40)$} & - Toy $(\mathrm{f}=7)$ \\
\hline & & - Dough-play dough $(\mathrm{f}=4)$ \\
\hline & & - Chameleon $(\mathrm{f}=4)$ \\
\hline & & - Weather $(\mathrm{f}=3)$ \\
\hline & & - Puzzle $(\mathrm{f}=2)$ \\
\hline & & - Football team $(\mathrm{f}=2)$ \\
\hline & & $\begin{array}{l}\text { Bus stop, Erase, Money, Glass, Fashion, the dice } \\
\text { thrown, Buttermilk churn, fickle, Environmental } \\
\text { pollution, Unknown way, Laboratory, Earth, } \\
\text { Orbit, Wheel, Palanquin, Time, Season, Human } \\
(\mathrm{f}=1)\end{array}$ \\
\hline & \multirow[b]{2}{*}{ Inefficient/Unsuccessful(f=9) } & - Infertile soil $(\mathrm{f}=2)$ \\
\hline & & $\begin{array}{l}\text { - Broken clock, Unarmed soldier, Non-wheeled car, } \\
\text { Utopia, Turtle, Factory, Injured child }(\mathrm{f}=1)\end{array}$ \\
\hline & \multirow{3}{*}{$\begin{array}{l}\text { Unsystematic/Complicated/ } \\
\text { Disorganized(f=9) }\end{array}$} & - Soup $(f=3)$ \\
\hline & & - Tangles $(\mathrm{f}=2)$ \\
\hline & & - Predicament, Knot, the Flu, Spider net $(\mathrm{f}=1)$ \\
\hline & $\begin{array}{l}\text { Collapsed/Exhausted } \\
(\mathrm{f}=4)\end{array}$ & $\begin{array}{l}\text { - Storm, Candle, Unstable foundation, Injured } \\
\text { gazelle with one leg }(\mathrm{f}=1)\end{array}$ \\
\hline \multirow{7}{*}{$\begin{array}{l}\text { Positive perception } \\
(\mathrm{f}=16)\end{array}$} & \multirow{3}{*}{ Egalitarian/Open to all $(\mathrm{f}=6)$} & - Orchard $(\mathrm{f}=2)$ \\
\hline & & $-\operatorname{Stars}(\mathrm{f}=2)$ \\
\hline & & - Rainbow, Forest $(\mathrm{f}=1)$ \\
\hline & \multirow{2}{*}{$\begin{array}{l}\text { Well-established and systematic } \\
(\mathrm{f}=5)\end{array}$} & $-\operatorname{Book}(\mathrm{f}=2)$ \\
\hline & & - Plane tree, Empty notebook, Matryoshka $(\mathrm{f}=1)$ \\
\hline & $\begin{array}{l}\text { Flexible / Open to development } \\
(\mathrm{f}=4)\end{array}$ & $\begin{array}{l}\text { - Tree, Child, Technology, Jointly drawn picture } \\
(\mathrm{f}=1)\end{array}$ \\
\hline & Important for the country $(\mathrm{f}=1)$ & - Heart $(f=1)$ \\
\hline $\begin{array}{l}\text { Neutral /descriptive } \\
\text { perception }(\mathrm{f}=2)\end{array}$ & Systematic/ Interdependent $(\mathrm{f}=2)$ & - Mosaic, Car engine $(\mathrm{f}=1)$ \\
\hline
\end{tabular}

Table 1 indicates that the majority of the metaphors produced by teacher candidates about the Turkish education system were negative $(f=62)$, which was followed by positive $(f=16)$ and neutral/descriptive $(f=2)$ metaphors, respectively. More than half of the negative metaphors produced by teacher candidates about the Turkish education system were related to the unceasing change of the system $(f=40)$. However, there were also teacher candidates who perceived the system as inefficient / unsuccessful $(f=9)$, unsystematic/ complicated/ disorganized $(f=9)$, and collapsed / exhausted $(f=4)$. The examples of the metaphors classified into sub-themes that the teacher candidates produced in relation to their negative perceptions of the Turkish education system are as follows:

- Constantly changing: "The Turkish education system is like a buttermilk churn because whoever is in the power is shaking it." (K13) 
- Inefficient/Unsuccessful: "The Turkish education system is like an unarmed soldier because the environment is suitable, everything is available, but it cannot yield full efficiency." (K66)

- Unsystematic/Complicated/Disorganized: "The Turkish education system is like the flu because it does not have a specific order and system; each system change harms students." (K38)

- Collapsed/Exhausted: "The Turkish education system is like a candle because it is melting and running out every other day." (K72)

Metaphors pointing out to positive perceptions of the Turkish education system were egalitarian/open to all ( $f=6$ ), well-established and systematic ( $f=5)$, flexible/open to development $(f=4)$, and important for the country $(f=1)$. The metaphor examples classified into sub-themes that the teacher candidates produced in relation to their positive perceptions of the Turkish education system are as follows:

- Egalitarian/open to all: "The Turkish education system is like a rainbow because it appeals to individuals of all ages." (K74)

- Well-established and systematic: "The Turkish education system is like a plane tree because it has a long history and many domains; it has a large domain like the branches of a plane tree." (K43)

- Flexible/open to development: "The Turkish education system is like technology because it is constantly changing and developing; it is open to changes and innovations." (K53)

- Important for the country: "The Turkish education system is like the heart in human body because if the education system fails, the whole country will collapse." (K35)

On the other hand, some of the teacher candidates produced metaphors representing a neutral/descriptive perception rather than a positive or negative perception of the Turkish education system. These metaphors were about systematic/ interdependent nature of the Turkish education system $(f=2)$. The example of the metaphor put into sub-themes that the teacher candidates produced regarding their neutral/descriptive perceptions of the Turkish education system is as follows:

- $\quad$ Systematic/ interdependent: "The Turkish education system is like a car engine because when one part breaks down, all parts break down and are affected." (K44)

\subsection{Teacher Candidates' Metaphorical Perceptions about School}

The second question in the study was about teacher candidates' metaphoric perceptions of the school concept. For this purpose, the participants were asked about what they compared the school to and why. The results were analyzed and described in Table 2. 
Table 2. Metaphors about school $(\mathrm{N}=82$, Valid=75)

\begin{tabular}{|c|c|c|}
\hline Themes & Sub-themes & Codes \\
\hline \multirow{11}{*}{$\begin{array}{l}\text { Positive } \\
\text { perception } \\
(\mathrm{f}=41)\end{array}$} & \multirow{6}{*}{$\begin{array}{l}\text { Educating/shaping people } \\
(\mathrm{f}=20)\end{array}$} & - Home $(f=4)$ \\
\hline & & - Factory $(\mathrm{f}=3)$ \\
\hline & & - Field $(\mathrm{f}=3)$ \\
\hline & & - Flower garden $(\mathrm{f}=2)$ \\
\hline & & - Soil $(\mathrm{f}=2)$ \\
\hline & & - Forest, Life, Book, Bakery, Workshop, Tree $(\mathrm{f}=1)$ \\
\hline & \multirow{4}{*}{$\begin{array}{l}\text { Giving a feeling of } \\
\text { belonging }(\mathrm{f}=16)\end{array}$} & - House $(f=6)$ \\
\hline & & - Home $(\mathrm{f}=5)$ \\
\hline & & - Family $(\mathrm{f}=4)$ \\
\hline & & - Shelter $(\mathrm{f}=1)$ \\
\hline & $\begin{array}{l}\text { Important for the system } \\
(\mathrm{f}=5)\end{array}$ & - Building blocks of matter, Human brain, Water, Breath, Sun $(\mathrm{f}=1)$ \\
\hline \multirow{8}{*}{$\begin{array}{l}\text { Negative } \\
\text { perception } \\
(\mathrm{f}=26)\end{array}$} & \multirow{2}{*}{$\begin{array}{l}\text { A place where one } \\
\text { wouldn't like to be }(f=10)\end{array}$} & - Prison $(f=8)$ \\
\hline & & - Aquarium, the Great Wall of China $(f=1)$ \\
\hline & $\begin{array}{l}\text { Cosmopolitan / Complex } \\
(\mathrm{f}=6)\end{array}$ & $\begin{array}{l}\text { - Nursing home, House with no key, Family, Potato field, World, } \\
\text { Public Midi bus ( } \mathrm{f}=1 \text { ) }\end{array}$ \\
\hline & Oppressive $(\mathrm{f}=4)$ & - State, Police Department, Workplace, Lantern ( $\mathrm{f}=1)$ \\
\hline & \multirow{2}{*}{ Uniformizing $(\mathrm{f}=3)$} & - Factory $(\mathrm{f}=2)$ \\
\hline & & - Prison $(\mathrm{f}=1)$ \\
\hline & Unsupervised $(\mathrm{f}=2)$ & - Lonely person, Hippodrome $(\mathrm{f}=1)$ \\
\hline & Inefficient $(\mathrm{f}=1)$ & - Hospital in a village $(\mathrm{f}=1)$ \\
\hline
\end{tabular}

Neutral /

descriptive Providing changing perception benefits $(\mathrm{f}=8)$ (f=8)

Table 2 shows that more than half of teacher candidates' perceptions about school were positive $(f=41)$, which was followed by negative $(f=26)$ and neutral/descriptive $(f=8)$ perceptions, respectively. The most positive perceptions of the teacher candidates about school were related to its educating / shaping nature $(f=20)$. Apart from this, there were also other teacher candidates who had a positive perception of school thinking that school provides a feeling of belonging $(f=9)$ and that it is important for the system $(f=5)$. The example metaphors classified into sub-themes that the teacher candidates produced related to their positive perceptions of school are as follows:

- Educating/shaping people: "School is like a field because it always grows up crops.” (K77).

- Giving a sense of belonging: "The school is like a home because it is open to anyone who wants to study and learn." (K67)

- Important for the system: "The school is like the sun because it is the source of life for the Earth." (K78)

The most negative perceptions of the teacher candidates about school identified it as a place where one wouldn't like to be $(f=10)$. This was followed by perceptions referring to school as a place that is cosmopolitan / complex $(f=6)$, oppressive ( $f=4)$, uniformizing ( $f=3$ ), unsupervised $(f=2)$, and inefficient $(f=1)$, respectively. The examples of metaphors classified into sub-themes that the teacher candidates produced regarding their negative perceptions of school are as follows:

- A place where one wouldn't like to be: "School is like a prison because students are treated like criminals who need to be held there from 8 am to $3 \mathrm{pm}$." (K45)

- Cosmopolitan / complex: "School is like a potato field because there may be rotten potatoes there as much as the healthy ones." (K23).

- Oppressive: "School is like a police department because too strict measures are taken to maintain discipline." (K17) 
- Uniformizing: "School is like a factory because it envisages educating students within certain standards, without going beyond stereotypes." (K52)

- Unsupervised: "In the Turkish education system, school is like a hippodrome because everyone rides their horse there as they like.” (K75).

- Inefficient: "In Turkey, school is like a hospital in a village because although it has every kind of facilities and possibilities, students, teachers, and administrators do not appreciate it as necessary." (K69)

In addition, some of the teacher candidates produced metaphors representing their neutral/descriptive perceptions rather than a positive or negative perception of the school. These metaphors were about changing benefits of school ( $f=8$ ). The following is a metaphor example classified into sub-themes that the teacher candidates produced regarding their neutral/descriptive perceptions about school.

- Providing changing benefits: "The school in Turkey is like a stove because it warms some and protects against cold, while it poisons others, not providing any benefits. ” (K19)

\subsection{Teacher Candidates' Metaphorical Perceptions about Teacher}

In line with the third question of the study, teacher candidates were asked about what they compared teachers to and why. The responses of the participants were analyzed and presented in Table 3.

Table 3. Metaphors about teacher $(\mathrm{N}=82$, Valid=74)

\begin{tabular}{|c|c|c|}
\hline Themes & Sub-themes & Codes \\
\hline \multirow{8}{*}{$\begin{array}{l}\text { Positive perception } \\
(\mathrm{f}=57)\end{array}$} & $\begin{array}{l}\text { Educating/shaping people } \\
(\mathrm{f}=17)\end{array}$ & $\begin{array}{l}\text { - Gardener }(\mathrm{f}=5) \\
\text { - Farmer }(\mathrm{f}=3) \\
\text { - Plaster-clay master }(\mathrm{f}=3) \\
\text { - Carpenter }(\mathrm{f}=2) \\
\text { - Mother-father, Baker, Artist, Tree }(\mathrm{f}=1)\end{array}$ \\
\hline & $\begin{array}{l}\text { Enlightening/Informing } \\
(\mathrm{f}=13)\end{array}$ & $\begin{array}{l}\text { - Light }(\mathrm{f}=3) \\
\text { - Flashlight }(\mathrm{f}=2) \\
\text { - The Sun, Rainbow, Lamp, Computer, Information } \\
\text { box, Cook, Greengrocer, Kitchen }(\mathrm{f}=1)\end{array}$ \\
\hline & Self-sacrificing $(\mathrm{f}=9)$ & $\begin{array}{l}\text { - Candle ( } \mathrm{f}=4) \\
\text { - Plaster, Flashlight, Khidr, Mirror, Miner }(\mathrm{f}=1)\end{array}$ \\
\hline & Model /Guiding (f=7) & $\begin{array}{l}\text { - Compass }(\mathrm{f}=2) \\
\text { - Arctic star, Guiding, Vessel, Mirror, Guide }(\mathrm{f}=1)\end{array}$ \\
\hline & $\begin{array}{l}\text { Setting up ties with students } \\
(\mathrm{f}=5)\end{array}$ & $\begin{array}{l}\text { - Family }(\mathrm{f}=3) \\
\text { - Mother-father }(\mathrm{f}=2)\end{array}$ \\
\hline & $\begin{array}{l}\text { Open to development and } \\
\text { innovation }(\mathrm{f}=3)\end{array}$ & - Technology, Student, Machine $(\mathrm{f}=1)$ \\
\hline & Important for the system $(\mathrm{f}=2)$ & - Reeve, Light $(\mathrm{f}=1)$ \\
\hline & Working systematically $(\mathrm{f}=1)$ & $-\operatorname{Clock}(\mathrm{f}=1)$ \\
\hline \multirow[t]{2}{*}{$\begin{array}{l}\text { Neutral/descriptive } \\
\text { perception }(f=9)\end{array}$} & Changeable $(f=7)$ & $\begin{array}{l}\text { - Lantern }(\mathrm{f}=2) \\
\text { - Fenerbahçe, BİM, Walnut, Clothing, USD Dollar } \\
\quad(\mathrm{f}=1)\end{array}$ \\
\hline & Caregiver $(\mathrm{f}=2)$ & - Parents, Caregiver $(\mathrm{f}=1)$ \\
\hline \multirow{2}{*}{$\begin{array}{l}\text { Negative perception } \\
(\mathrm{f}=8)\end{array}$} & Unappreciated in society $(\mathrm{f}=6)$ & $\begin{array}{l}\text { - Syrian worker, Standard worker, Cat, USD Dollar, } \\
\text { Invisible man, Water }(\mathrm{f}=1)\end{array}$ \\
\hline & Slothful(f=2) & $\begin{array}{l}\text { - Making money with not much effort, Body with no } \\
\text { spirit }(\mathrm{f}=1)\end{array}$ \\
\hline
\end{tabular}


Table 3 shows that more than two-thirds of teacher candidates' perceptions of teacher were positive $(f=57)$, and this was followed by neutral/descriptive $(f=9)$, and negative $(f=8)$ perceptions, respectively. Teacher candidates' positive perceptions of teacher were mostly about "educating/shaping people" nature of the profession $(\mathrm{f}=17)$. This was followed by other characteristics of the teaching profession such as enlightening / informing ( $\mathrm{f}=13$ ), self-sacrificing ( $f=9$ ), model / guiding ( $f=7$ ), setting up ties with students $(f=5)$, open to development and innovation ( $f=3$ ), important for the system ( $f=2$ ), and working systematically $(f=1)$, respectively. The examples of metaphors classified into sub-themes that the teacher candidates produced regarding their positive perceptions of teacher are as follows:

- Educating/shaping people: "A teacher is like a gardener because they educate and shape children." (K37)

- Enlightening / Informing: "A teacher is like a flashlight because they shed light on students' future.” (K61)

- Self-sacrificing: "Teachers in Turkey are like a candle because they self-sacrifice while trying to illuminate their circles." (K57)

- Model / Guiding: "A teacher is like the Polar Star because they always show the right path." (K8)

- Setting up ties with students: "A teacher is like a family because they do their job by building strong ties with students." (K79)

- Open to development and innovation: "A teacher is like a student. They constantly show curiosity, question, and search for things." (K32)

- Important for the system: "A teacher is like a reeve in Turkey because everything is asked of them." (K60)

- Working systematically: "A teacher is like a clock because they always work in a planned manner." (K22)

Metaphors related to neutral / descriptive perceptions followed the metaphors that expressed the positive perceptions of the majority of teacher candidates about teacher. These metaphors were about changeable feelings towards teaching $(f=7)$ and about caregiver task $(f=2)$ of the teaching profession. The metaphor examples classified into sub-themes that the teacher candidates produced regarding their neutral/descriptive perceptions of teacher are as follows:

- Changeable: "A teacher is like Fenerbahce (football team) because you sometimes get angry with it, but you love it wholeheartedly." (K1)

- Caregiver: "A teacher is like a parent because students spend most of the day with their teachers." (K7)

The most negative perceptions of the teacher candidates about teacher were based on the idea that teachers are unappreciated in society $(f=6)$. There were also teacher candidates who perceived teacher as slothful $(f=2)$. The metaphor examples classified into sub-themes that the teacher candidates produced relating to their negative perceptions of teacher are as follows:

- Unappreciated in society: "A teacher is like a Syrian worker because he is not appreciated, he gets little money, but a lot of work is expected". (K41)

- Slothful: "A teacher is like a body with no spirit. This is the case when considering the average age of current teachers and considering the fact that they do not deserve the salary they get and they are irresponsible." (K69)

\subsection{Teacher Candidates' Metaphorical Perceptions about Student}

The last question that was sought an answer in the study was teacher candidates' perceptions of student. In order to find an answer to this question, the participants were asked what they compared the students to and why. 
Table 4. Metaphors about student $(\mathrm{N}=82$, Valid=77)

\begin{tabular}{|c|c|c|}
\hline Themes & Sub-themes & Codes \\
\hline \multirow{9}{*}{$\begin{array}{l}\text { Positive perception } \\
(\mathrm{f}=41)\end{array}$} & \multirow{3}{*}{$\begin{array}{l}\text { A person that can be shaped } \\
(\mathrm{f}=17)\end{array}$} & $-\operatorname{Dough}(f=7)$ \\
\hline & & - Plaster-clay $(\mathrm{f}=2)$ \\
\hline & & $\begin{array}{l}\text { - Vase, Sapling, Tree, Seed, Future, Unripe fruit, Child, } \\
\text { Apprentice }(\mathrm{f}=1)\end{array}$ \\
\hline & \multirow{3}{*}{ Having potentials $(\mathrm{f}=13)$} & - Flower $(\mathrm{f}=3)$ \\
\hline & & - Mine $(\mathrm{f}=2)$ \\
\hline & & $\begin{array}{l}\text { - Pearl, Board, Earth, Soil, Raw stone, Gold bar, Magic } \\
\text { box, Jewelry }(\mathrm{f}=1)\end{array}$ \\
\hline & \multirow[b]{2}{*}{ Willing to learn $(\mathrm{f}=9)$} & - Notebook $(\mathrm{f}=2)$ \\
\hline & & $\begin{array}{l}\text { - Water drop, Book, Tree, Wheat, Computer, Candle, } \\
\text { Snowball }(\mathrm{f}=1)\end{array}$ \\
\hline & Important for the system $(\mathrm{f}=2)$ & - Blood in vein, Foundation of building structure $(\mathrm{f}=1)$ \\
\hline \multirow{7}{*}{$\begin{array}{l}\text { Negative perception } \\
(\mathrm{f}=29)\end{array}$} & Made to overwork $(\mathrm{f}=9)$ & $\begin{array}{l}\text { - Racehorse, Snow, Porter, Refrigerator, Worker, Bee, } \\
\text { Ant, Slave }(\mathrm{f}=1)\end{array}$ \\
\hline & Uniformly educated $(\mathrm{f}=9)$ & $-\operatorname{Robot}(\mathrm{f}=2)$ \\
\hline & & $\begin{array}{l}\text { - Footballer, Soldier, Slave, Isosceles, Blank board, } \\
\text { Factory, Cake mold }(\mathrm{f}=1)\end{array}$ \\
\hline & \multirow[t]{2}{*}{ Unappreciated $(\mathrm{f}=6)$} & - Garbage $(\mathrm{f}=3)$ \\
\hline & & - Philosopher, Unappreciated mine, Orphan child $(\mathrm{f}=1)$ \\
\hline & Educated unsystematically $(\mathrm{f}=3)$ & - Kitten, Pendulum, Subject $(\mathrm{f}=1)$ \\
\hline & Useless $(\mathrm{f}=2)$ & - Lazy person, Garbage $(\mathrm{f}=1)$ \\
\hline $\begin{array}{l}\text { Neutral/ Descriptive } \\
\text { perception }(f=8)\end{array}$ & $\begin{array}{l}\text { Having individual differences } \\
(\mathrm{f}=8)\end{array}$ & $\begin{array}{l}\text { - Sapling }(\mathrm{f}=2) \\
\text { - Walnut, Horse in the lane, Fruit basket, Colorful } \\
\text { flower, Coal, Watermelon }(\mathrm{f}=1)\end{array}$ \\
\hline
\end{tabular}

Table 4 indicates that nearly three-quarters of teacher candidates' perceptions about student were positive $(\mathrm{f}=41)$. This was followed by negative $(\mathrm{f}=29)$ and neutral / descriptive $(\mathrm{f}=8)$ perceptions, respectively. The most positive perceptions of the teacher candidates about student were based on the idea that student can be shaped $(\mathrm{f}=17)$. This was followed by other perceptions such as having potentials $(f=13)$, willingness to learn $(f=9)$, and being important for the system $(\mathrm{f}=2)$, respectively. The example metaphors classified into sub-themes that the teacher candidates produced regarding their positive perceptions of student are as follows:

- Can be shaped: A student is like dough because they can be shaped as you like." (K11)

- With potentials: A student is like a pearl because the beauties are revealed as they unfold. (K30)

- Willing to learn: A student is like a notebook because they want to be filled out. (K15)

- Important for the system: A student is like blood in the vein because they are the main recipient element of the system whose project has been prepared." (K48)

The most negative perceptions of the teacher candidates were based on the idea that students were made to overwork ( $f=9$ ). This was followed by the perceptions that the education system was uniformizing students $(f=9)$, students were unappreciated $(f=6)$, students were educated unsystematically $(f=3)$, and that students were seen as useless ( $f$ $=2$ ), respectively. The metaphor examples classified into sub-themes that teacher candidates produced regarding their negative perceptions of student are as follows:

- Made to overwork: “A student is like a worker, studies day and night.” (K64)

- Uniformly educated: “A student is like a factory, made up of certain personalities.” (K20) 
- Unappreciated: "A student is like an orphan child, always in need of things.” (K68)

- Educated unsystematically: "A student is like a subject because every innovation is tested on them." (K56)

- Useless: "A student is like a lazy person because they confine themselves to the simplest things they do and don't want to get out of there." (K50)

On the other hand, some teacher candidates produced neutral/descriptive perceptions of student instead of positive or negative perception. These metaphors were about the individual differences of student $(f=8)$. The metaphor sample classified into sub-theme that teacher candidates produced related to their neutral/descriptive perceptions about student is given below:

- With individual differences: "A student is like a fruit basket because a basket involves a lot of fruits which are unripe or taste rotten." (K80)

\section{Discussion}

The majority of the primary school teacher candidates participating in the study had a negative perception of the Turkish education system. More than half of the negative metaphors produced by the participants regarding the Turkish education system were related to the unceasing changes in the system. The primary school teacher candidates thought that the Turkish education system was inefficient, disorderly, and collapsed. Studies (e.g. Akın, 2016) show that the frequent efforts of change in the Turkish education system have also been perceived negatively by educators, too. It seems that the changes, innovations or reform attempts made without considering the superiority and applicability of the old practice negatively affect the perceptions of the primary school teacher candidates. In recent years, a number of changes have been made in the Turkish education system covering different levels of education. Unstable planning such as deciding to carry out education with handwriting in first-grade reading instruction and then abandoning it, decreasing the five-year primary school duration to four years, changing the age of schooling several times, indecisive planning on making pre-school education compulsory, and similar attempts cause negative perceptions in the prospective classroom teachers as well as educators.

Primary school teacher candidates' perceptions of the school concept were mostly positive. The participants saw the school as a home that educates and shapes people. However, a significant number of the participants perceived school as an oppressive prison uniformizing people, where nobody would like to be. In addition to the general positive perception, the perception of the school as a prison. People had a considerably high proportion; thus, it is evaluated to be a result that should be taken into consideration. In general, studies (e.g. Aydoğdu, 2008; Nalçacı \& Bektaş, 2012; Örücü, 2014) show that positive perceptions of school are accompanied by a significant amount of negative perceptions. The important question is what makes up the basis of these negative perceptions of teacher candidates and how these perceptions can be turned into positives. According to the findings of Saban (2003), negative school experiences are the basis of these negative perceptions. Students' school experiences and perceptions of school are negatively influenced by teacher behaviors that are boring, rude, unhelpful, irritable, punitive, emphasizing hierarchical position, discriminating among students, giving too much homework, and having students compete through exams. Undoubtedly, the programs we offered to students in Turkish schools, the way they conduct lessons, the school buildings, play and sports areas, and socialization opportunities are important factors that affect the perception of school. Which of these factors or what other variables underlie the basis of negative school perception may be the subject of further research.

Primary school teacher candidates' perceptions of the teacher concept were mostly positive, despite evidence of neutral and negative perceptions. Teacher candidates' description of the teacher concept mainly emphasized the "educating and shaping people" property. Here, metaphors related to nurturing and shaping such as "gardener", "farmer", "plaster master" and "carpenter" come to the fore. There are many studies in the literature showing that the concept of teacher is described with grower-gardener or farmer metaphors (Pektaş and Kildan, 2009; Saban, 2003; Saban et al., 2006; Turan et al., 2016). Metaphors such as formative-plaster master or carpenter or similar ones are often used to describe teachers (Aydın \& Pehlivan, 2010; Karabay, 2016; Saban, 2004; Saban et al., 2006; Y1lmaz et al., 2013). These perceptions reflect a perception that complies with the behavioral approach where the teacher is in the center and the student is passive. Indeed, constructivist learning and teaching concept has been the most studied concept in educational faculties in Turkey for the last 15 years and the most emphasized topic by teaching staff. The findings of Martinez et al. (2001) indicated that experienced teachers in Spain described the learning process more from a behavioral perspective and saw teachers as transmitters of knowledge. However, teacher candidates described the learning-teaching process mostly with constructivist metaphors. According to the findings of Mahlios and Maxson (1998), primary school teacher candidates in the United States produced metaphors that described teaching 
as guiding, nurturing, stimulating, and telling. Although the constructivist approach is greatly emphasized in educational faculties in Turkey greatly, it is interesting that primary school teacher candidates produced a relatively small number of metaphors complying with the constructivist approach. Further research may specifically focus on this topic.

Although the primary school teacher candidates' perceptions of the student were generally positive. On the other hand, it seems they had a student perception that students were passive and shapable in the learning process. The teacher candidates who used metaphors for teacher such as plaster master and carpenter, similarly regarded student as a passive learner with metaphors such as dough, clay, and plaster. Similarly, previous studies (Aydın \& Pehlivan, 2010; Koçak, 2013; Mahlios \& Maxson, 1998; Saban, 2009; Saban, 2010) showed that a passive student perception emerged. In addition, a significant number of teacher candidates thought that students are made to overwork (a racehorse), they are uniformized (robot), they are not given the value they deserve (orphan child), and that they are educated unsystematically (subject). Problems such as test-centered education, overloaded curriculum, and insufficient consideration of individual differences, which are thought to be underlying this negative perception, have long attracted the attention of the Ministry of National Education. The 2023 Education Vision Document (MEB, 2019) offers promising solutions to all of these problems. As stated in the document, if examinations, over-diversity of the courses in which students are responsible for, the course hours, and swollen content can be reduced and different options that take into account the differences and interests of students can be offered, the perception of poor student may start to change as well.

\section{References}

Afacan, Ö. (2011). Metaphors used by elementary science teacher candidates to describe "science" and "elementary science and technology teacher". e-Journal of New World Sciences Academy, 6(1), 1242-1254.

Akgün, E. (2016). Prospective pre-school teachers' metaphors about the concept of "child" and "pre-school teacher". Abant İzzet Baysal Üniversitesi Eğitim Fakültesi Dergisi, 16(4), 1652-1672.

Akın, U. (2016). Innovation efforts in education and school administration: Views of Turkish school administrators. Euroasian Journal of Educational Research, 63, 243-260. https://doi.org/10.14689/ejer.2016.63.14

Alım, M., Şahin, İ.F., \& Meral, E. (2018). Geography prospective teachers' (pedagogical formation) perceptions of the concept of teacher. Atatürk University Journal of Graduate School of Social Sciences, 22(2), 113-127.

Arslan, M. M. \& Bayrakc1, M. (2006). An examination of metaphorical thinking and learning from educational view. National Education, 171, 100-108.

Aydın, İ.S. \& Pehlivan, A. (2010). The metaphors that Turkish teacher candidates use concerning "teacher" and "student" concepts. Turkish Studies, 5(3), 818-842. https://doi.org/10.7827/TurkishStudies.1465

Aydoğdu, E. (2008). The analyze of perceptions that primary students and teachers have on the school life and ideal school life by using metaphors (Unpublished master's thesis). Eskişehir Osmangazi University, Eskişehir, Turkey.

Baker, P. J. (1991). Metaphors of mindful engagement and a vision of better schools. Educational Leadership, 48(7), 32-35.

Bedir Erişti, S. D. (2017). The metaphoric perception of teacher candidates related 'fine arts teacher' concept. İn̈̈n̈ University Journal of the Faculty of Education, 18(1), 265-280. https://doi.org/10.17679/inuefd.306631

Boostrom, R. (1998). 'Safe spaces': Reflections on an educational metaphor. Journal of Curriculum Studies, 30(4), 397-408. https://doi.org/10.1080/002202798183549

Bramald, R., Hardman, F., \& Lead, D. (1995). Initial teacher trainees and their views of teaching and learning. Teaching \& Teacher Education, 11(1), 23-31. https://doi.org/10.1016/0742-051X(94)E0009-T

Budak, Y. \& Kula, S. S. (2017). Perceptions of teacher candidates about teaching as a profession. Ahi Evran University Journal of Kırşehir Education Faculty, 18(2), 311-329.

Carlson, T. B. (2001). Using metaphors to enhance reflectiveness among preservice teachers. Journal of Physical Education, Recreation \& Dance, 72(1), 49-53. https://doi.org/10.1080/07303084.2001.10605820

Cerit, Y. (2006). School metaphors: The views of students, teachers and administrators. Educational Sciences: Theory \& Practice, 6(3), 692-699.

Cerit, Y. (2008). Students, teachers and administrators' views on metaphors with respect to the concept of teacher. 
The Journal of Turkish Educational Sciences, 6(4), 693-712.

Creswell, J. W. (2012). Research design: Qualitative, quantitative, and mixed methods approaches (4nd ed.). United States: Pearson Education Limited.

Çelikten, M. (2006). Culture and teacher metaphors used in educational system. Erciyes University Journal of Social Sciences, 21(2), 269-283. https://doi.org/10.3844/jssp.2006.21.26

Çulha Özbaş, B. \& Aktekin, S. (2013). Investigating prospective history teachers' beliefs on history teachers through metaphor analysis. Journal of Theory and Practice in Education, 9(3), 211-228.

Doğan, D. (2014). Analysis of the school concept through the perspectives of candidate teachers via metaphors. Journal of Theoretical Educational Science, 7(3), 361-382. https://doi.org/10.5578/keg.7127

Giren, S. (2015). Pre-service early childhood education teachers' metaphors about early childhood teacher concept. Firat University Journal of Social Science, 25(2), 123-132.

Goldstein, L.S. (2005). Becoming a teacher as a hero's journey: Using metaphor in preservice teacher education. Teacher Education Quarterly, 32(1), 7-24.

Işı, Ö. (2014). Analyzing the pre-service classroom teacher's perceptions through metaphors which are related to teacher, teaching and learning from the point of constructivism (Unpublished master's thesis). Pamukkale University, Denizli, Turkey. https://doi.org/10.1080/09720073.2014.11891551

Kahya, H. (2018). An investigation of metaphors on the concept of literature teacher among preservice Turkish language and literature teachers in Turkey. Journal of the International Scientific Researches, 3(1), 104-117. https://doi.org/10.21733/ibad.343188

Kalyoncu, R. (2012). Visual arts teacher candidates' metaphors related to concept of "teaching". Mustafa Kemal University Journal of Social Sciences Institute, 9(20), 471-484.

Karabay, A. (2016). An investigation of prospective teachers' views regarding teacher identity via metaphors. Eurasian Journal of Educational Research, 65, 1-18. https://doi.org/10.14689/ejer.2016.65.01

Kasapoğlu, H. (2016). Analysis of teacher candidates perception's of Turkish national education system through metaphors. Educational Administration: Theory and Practice, 22(1), 59-80. https://doi.org/10.14527/kuey.2016.003

Keser Özmantar, Z. \& Yalçın Arslan, F. (2019). Metaphorical perceptions of prospective EFL teachers related to Turkish education system. Pegem Journal of Education and Instruction, 9(1), 255-304. https://doi.org/10.14527/pegegog.2019.009

Kiral, E. (2015). Teacher metaphors according to the perceptions of prospective teachers. Adnan Menderes University Faculty of Education Journal of Educational Sciences, 6(1), 57-65.

Koç, E.S. (2014). Sınıf öğretmeni adaylarının öğretmen ve öğretmenlik mesleği kavramlarına ilişkin metaforik algilar1 [Metaphorical perceptions of classroom teacher candidates about the concepts of teacher and teaching profession]. Inönü University Journal of the Faculty of Education, 15(1), 47-72. https://doi.org/10.17679/iuefd.79408

Koçak, C. (2013). Metaphorical perceptions of teacher candidates towards the school concept: lotus flower model. Mevlana International Journal of Education, 3(4), 43-56. https://doi.org/10.13054/mije.13.61.3.4

Lakoff, G., \& Johnson, M. (1980). Metaphors we live by. Chicago: The University of Chicago Press.

Levine, P.M. (2005). Metaphors and images of classrooms. Kappa Delta Pi Record, 41(4), 172-175. https://doi.org/10.1080/00228958.2005.10532066

Mahlios, M. \& Maxson, M. (1998). Metaphors as structures for elementary and secondary preservice teachers' thinking. International Journal of Educational Research, 29, 227-240. https://doi.org/10.1016/S0883-0355(98)00027-5

Martinez, M.A., Sauleda, N., \& Huber, G.L. (2001). Metaphors as blueprints of thinking about teaching and learning. Teaching and Teacher Education, 17, 965-977. https://doi.org/10.1016/S0742-051X(01)00043-9

MEB (2019). 2023 Education Vision Paper. Retrieved from http://2023vizyonu.meb.gov.tr/ at 04.07.2019.

Nalçac1, A. \& Bektaş, F. (2012). Teacher candidates’ perceptions regarding the concept of school. Ahi Evran University Journal of Kırşehir Education Faculty, 13(1), 239-258. 
Ocak, G. \& Gündüz, M. (2006). The comparison of pre-service teachers' metaphors about the teacher-profession before and after the 'introduction to teacher-profession' course. Afyon Kocatepe University Journal of Social Sciences, 8(2), 293-310.

Örücü, D. (2014). Pre-service teachers' metaphors towards school, school administrators and Turkish education system. Educational Administration: Theory and Practice, 20(3), 327-358. http://dx.doi.org/10.14527/kuey.2014.014

Pektaş, M. \& Kıldan, A.O. (2009). A comparison of "teacher" metaphors generated by preservice teachers from different majors. Erzincan University Journal of Education Faculty, 11(2), 271-287.

Saban, A. (2003). A Turkish profile of prospective elementary school teachers and their views of teaching. Teaching and Teacher Education, 19, 829-846. https://doi.org/10.1016/j.tate.2003.03.004

Saban, A. (2004). Entry level prospective classroom teachers' metaphors about the concept of "teacher". The Journal of Turkish Educational Sciences, 2(2), 131-155.

Saban, A. (2008). Metaphors about school. Educational Administration: Theory and Practice, 55, 459-496.

Saban, A. (2009). Prospective teachers' mental images about the concept of student. The Journal of Turkish Educational Sciences, 7(2), 281-326.

Saban, A. (2010). Prospective teachers' metaphorical conceptualizations of learner. Teaching and Teacher Education, 26, 290-305. https://doi.org/10.1016/j.tate.2009.03.017

Saban, A., Koçbeker, \& Saban, A. (2006). An investigation of the concept of teacher among prospective teachers through metaphor analysis. Educational Sciences: Theory \& Practice, 6(2), 509-522.

Şahin, B. (2013). Teacher candidates' metaphoric perceptions related with "mathematics teacher", "mathematics" and "math lesson" concepts. Mersin University Journal of the Faculty of Education, 9(1), 313-321.

Şahin, A. \& Sabanc1, A. (2018). Perceptions of prospective teachers attending pedagogical formation courses regarding the school administrators and teachers: A metaphorical study. Turkish Studies, 13(4), 1057-1082. https://doi.org/10.7827/TurkishStudies.12902

Turan, M., Yıldırım, E., \& T1kman, F. (2016). Metaphorical perceptions of pre-service teachers training and some basic concepts. NWSA Education Sciences, 11(4), 217-242. https://doi.org/10.12739/NWSA.2016.11.4.1C0663

Uslu, S. (2015). Metaphorical perceptions of preservice social studies teacher towards the concept of "social studies teacher". Educational Research and Reviews, 10(7), 804-810. https://doi.org/10.5897/ERR2015.2121

Yadigaroğlu, M., Demircioğlu, G., Yadigaroğlu, H., \& Akar, H. (2018). Metaphorical perceptions of science teacher candidates towards teacher and teaching profession. International Journal on New Trends in Education and Their Implications, 9(3), 1-10.

Yıldırım, A. \& Şimşek, H. (2011). Sosyal bilimlerde nitel araştırma yöntemleri. (8. Baskı). Ankara: Seçkin Yayincilik.

Yılmaz, F., Göçen, S., \& Yılmaz, F. (2013). Pre-service teachers' perceptions of the concept of teacher: A metaphoric study. Mersin University Journal of the Faculty of Education, 9(1), 151-164.

Yob, I.M. (2003). Thinking constructively with metaphors. Studies in Philosophy and Education, 22, 127-138. https://doi.org/10.1023/A:1022289113443

Yüksel, H.S., Sütçü, Ö., \& Özdemir, B. (2019). Exploring of prospective teachers' metaphoric perceptions about the concepts of "physical education course" and "physical education teacher". Journal of Education and Learning, 8(2), 58-68. https://doi.org/10.5539/jel.v8n2p58 